\title{
PENGEMBANGAN MODEL STRATEGI PEMENUHAN JAM WAJIB PENGEMBANGAN KOMPETENSI BAGI PEGAWAI NEGERI SIPIL DI LINGKUNGAN PEMERINTAH PROVINSI KALIMANTAN BARAT
}

\author{
Development Model Strategy of Compulsory Learning Hours for Civil Servants \\ Competency Development in The Government of The West Kalimantan Province
}

\section{Fransiscus Febrisoni}

Badan Pengembangan Sumber Daya Manusia Provinsi

Kalimantan Barat

email:

fransiscustimothy@gmail.com

\begin{abstract}
Abstrak
Pemerintah menetapkan wajib jam pengembangan kompetensi sebanyak 20 Jam Pelajaran (JP) per tahun bagi setiap PNS. Hal ini tentunya tidak mudah untuk dilakukan mengingat jumlah PNS yang sangat banyak dan anggaran yang terbatas. Untuk itu maka BPSDM Provinsi Kalimantan Barat memerlukan strategi agar kewajiban tersebut dapat terpenuhi untuk setiap PNS. Penelitian ini bertujuan untuk mencari strategi terbaik pengembangan kompetensi bagi PNS di lingkungan Pemerintah Provinsi Kalimantan Barat, kemudian memberikan alternatif model sebagai pemecahan masalah. Metode penelitian menggunakan pendekatan deskriptif kualitatif, dengan pengumpulan data menggunakan studi literatur, pengumpulan data sekunder dan dokumentasi. Hasil penelitian menunjukkan bahwa model alternatif terbaik yang dapat dilakukan oleh BPSDM Provinsi Kalimanan Barat untuk memenui kewajiban $20 \mathrm{JP}$ per tahun bagi setiap PNS secara efisien adalah dengan memperbanyak kegiatan yang dapat dilakukan secara massal adalah on the job training (OJT), disamping masih ada kegiatan pelatihan full e-learning, pelatihan blended learning, workshop/seminar, bimbingan teknis, coaching. Dengan menerapkan komposisi hitungan pelaksanaan OJT yang dijelaskan dalam analisis, BPSDM membutukkan biaya sebesar Rp I.843.250.000,- untuk mencukupi $20 \mathrm{JP}$ bagi I0.825 PNS di Pemerintah Provinsi Kalimantan Barat.
\end{abstract}

Kata Kunci:

20 jam pelajaran wajib

Model simulasi

Peningkatan kompetensi

ASN/PNS

\section{Keywords:}

Compulsory 20 learning hours

Simulation model

Increasing public servant

competency

\begin{abstract}
The government sets mandatory competency development hours of 20 Learning Hours $(\mathrm{LH})$ per year for each civil servant. This is certainly not easy to do given a large number of civil servants and a limited budget. For this reason, BPSDM West Kalimantan Province needs a strategy so that these obligations can be fulfilled for every civil servant. This study aims to find the best strategy for developing competencies for civil servants in the Provincial Government of West Kalimantan, then providing alternative models as problemsolving. The research method uses a qualitative descriptive approach, with data collection using literature studies, secondary data collection and documentation. The results showed that the best alternative model that could be carried out by BPSDM West Kalimantan Province to fulfill the obligations of $20 \mathrm{JP}$ per year for each civil servant efficiently was to multiply activities that could be carried out en masse is on the job training (OJT), besides there are still full e-learning training, blended learning training, workshops/seminars, technical guidance, coaching. By applying the composition of OJT implementation calculations described in the analysis, BPSDM requires a fee of $R p 1.843 .250 .000$,- to cover $20 \mathrm{LH}$ for 10,825 civil servants in West Kalimantan.
\end{abstract}

\section{PENDAHULUAN}

Pemerintah telah menetapkan wajib jam pengembangan kompetensi sebanyak 20 Jam Pelajaran (JP) bagi setiap PNS dalam satu tahun. Ketentuan tersebut muncul dalam PP No. II Tahun 2017 tentang
Manajemen PNS. Pemenuhan terhadap kebutuhan tersebut merupakan sebuah tantangan besar, seperti juga dikatakan oleh Sumanti (2018) bahwa memenuhi kebutuhan $20 \mathrm{JP}$ tersebut merupakan sebuah tantangan bagi lembaga pelatihan pemerintah. Kemudian juga 
diungkapkan oleh Apandi (2010) bahwa pengembangan kompetensi PNS merupakan tantangan yang sangat rumit, namun bukan berarti tidak ada solusi untuk menuntaskannya.

Terdapat beberapa penelitian yang membahas tentang strategi pengembangan kompetensi PNS, seperti Ayas dan Sinaga (2019) yang membahas metode understudies, job rotation dan coaching sebagai strategi pengembangan kompetensi di Kabupaten Serdang Bedagai. Apandi (2020) juga membahas strategi pengembangan kompetensi melalui e-literasi dan edukasi kebijakan publik secara umum. Selanjutnya Ismail et.al (2018) mengungkapkan bahwa faktor pimpinan berpengaruh terhadap keberhasilan pengembangan kompetensi. Kemudian Sultoni (2020) di Provinsi Jambi dan Mulyaningsih (2020) di Kota Magelang sama-sama mengungkapkan pentingnya analisis kebutuhan pengembangan kompetensi sebagai strategi pengembangan kompetensi.

Meskipun sudah terdapat beberapa penelitian yang membahas tentang pengembangan kompetensi PNS, namun yang membahas tentang pengembangan model strategi pengembangan kompetens PNS dalam ruang lingkup pemerintah daerah masih terbatas. Oleh karena itu penelitian ini berupaya untuk mencari model strategi terbaik dalam pengembangan kompetensi PNS yang dilakukan oleh BPSDM Provinsi Kalimantan Barat.

Badan Pengembangan Sumber Daya Manusia (BPSDM) Provinsi Kalimantan Barat selaku leading sector dalam pengembangan sumber daya manusia aparatur di Provinsi Kalimantan Barat, ditantang untuk dapat menjawab berbagai persoalan kesenjangan atau gap dari setiap kompetensi PNS. Sejalan dengan Setiadiputra (2017) bahwa pemerintah membentuk BPSDM untuk melakukan pengembangan kompetensi di lingkungan instansi pemerintah. BPSDM dituntut untuk mampu melakukan upaya-upaya dalam rangka percepatan pengembangan kompetensi PNS secara berkualitas dan berdampak luas seperti yang diungkapkan oleh Madjid (2019).

$$
\text { Sesuai dengan Peraturan Gubernur }
$$

Kalimantan Barat Nomor 99 Tahun 2019 tentang Perubahan Peraturan Gubernur Nomor 124 Tahun 2016 tentang Kedudukan, Susunan Organisasi, Tugas Dan Fungsi Serta Tata Kerja Badan Pengembangan Sumber Daya Manusia Provinsi Kalimantan Barat, BPSDM mempunyai tugas dalam perumusan program kerja, perumusan kebijakan, pelaksanaan kebijakan dan penyelenggaraan kegiatan di bidang pengembangan sumber daya manusia. Pergub tersebut mempunyai makna bahwa BPSDM mempunyai tanggung jawab terhadap pengembangan kompetensi bagi seluruh PNS di lingkungan Pemerintah Provinsi Kalimantan Barat.

Berdasarkan data Badan Kepegawaian Daerah Provinsi Kalimantan Barat per Maret 2020, jumlah PNS di lingkungan Pemprov Kalbar adalah 10.825 PNS. Adapun rincian jumlah PNS tersebut dapat dijabarkan sebagai berikut:

Tabel I.

Jumlah PNS di Lingkungan Pemprov Kalbar

\begin{tabular}{|c|c|c|}
\hline No & Klasifikasi Jabatan & Jumlah \\
\hline I. & Jabatan struktural & 1035 \\
\hline 2. & Fungsional Tertentu & 5743 \\
\hline 3. & Fungsional Umum & 4047 \\
\hline & Jumlah Total & 10.825 \\
\hline \multicolumn{3}{|c|}{ Sumber: BKD Prov. Kalbar 2020 } \\
\multicolumn{3}{|c|}{ Selanjutnya, sejak PP No. II Tahun 2017 }
\end{tabular}

diberlakukan, BPSDM telah menyelenggarakan berbagai kegiatan pengembangan kompetensi. Adapun jumlah alumni kegiatan pengembangan kompetensi BPSDM tahun 2017-2019 adalah sebagai berikut:

Tabel II.

Jumlah Alumni BPSDM Prov. Kalbar 2017-2019

\begin{tabular}{|c|c|c|}
\hline No & Tahun & Jumlah Alumni \\
\hline I. & 2017 & 1.134 \\
\hline 2. & 2018 & 1.143 \\
\hline 3. & 2019 & 2.494 \\
\hline & Total & $4.77 \mid$ \\
\hline
\end{tabular}

Sumber: BPSDM Prov. Kalbar 2017-2019 
Dari tabel tersebut dapat dilihat bahwa dari tahun 20I7-20I9 BPSDM telah berhasil meningkatkan jumlah alumni. Namun jika dibandingkan dengan jumlah PNS yang ada di lingkungan Pemprov Kalbar sebanyak 10.825 PNS, maka BPSDM hanya memiliki kapasitas mengembangkan kompetensi sebanyak $23 \%$ dari jumlah keseluruhan PNS. Oleh karena itu, sebagai leading sector pengembangan sumber daya manusia di Pemprov Kalbar, maka BPSDM diharapkan memiliki strategistrategi dalam rangka pemenuhan pengembangan kompetensi minimal sebanyak 20 JP bagi setiap PNS dalam satu tahun.

Di dalam Peraturan LAN No. 10 Tahun 2018 tentang Pengembangan Kompetensi PNS, disebutkan bahwa kompetensi merupakan pengetahuan, keterampilan, dan sikap/perilaku yang dapat diamati, diukur, dan dikembangkan dalam melaksanakan tugas pekerjaannya. Definisi tersebut juga didukung oleh Burkholder et.al (2007) dan Muda (2019) yang juga menyampaikan bahwa kompetensi berkaitan dengan pengetahuan, keterampilan dan perilaku sesorang.

Dari definisi kompetensi tersebut di atas dapat dikatakan bahwa kompetensi PNS merupakan suatu hal yang harus dikembangkan supaya PNS tersebut dapat melaksanakan tugas jabatannya dengan baik. Hal tersebut juga dikemukakan oleh Fathurrochman (2017), bahwa pengembangan kompetensi PNS merupakan upaya untuk meningkatkan kinerja dan mencapai tujuan organisasi berdasarkan visi-misi setiap organisasi.

Di dalam pasal II2 PP tersebut ditegaskan bahwa setiap PNS memiliki hak dan kesempatan untuk diikutsertakan dalam pengembangan kompetensi paling sedikit 20 Jam Pelajaran (JP) dalam satu tahun. Ditambahkan lagi pada pasal 116, bentuk pengembangan kompetensi dibagi menjadi dua, yaitu melalui pendidikan dan melalui pelatihan. Jalur pendidikan dilakukan dengan pemberian tugas belajar kepada PNS untuk meningkatkan jenjang pendidikan formalnya.

Pengembangan kompetensi jalur pelatihan, dapat dilakukan melalui pelatihan klasikal dan pelatihan nonklasikal. Pelatihan klasikal dapat dilakukan lewat pembelajaran tatap muka di kelas, seperti pelatihan, seminar, kursus dan penataran. Pelatihan nonklasikal dapat dilakukan lewat e-learning, bimbingan di tempat kerja, pelatihan jarak jauh, magang dan pertukaran antara PNS dengan pegawai swasta.

Oleh karena penelitian ini membahas tentang strategi, maka disampaikan juga konsep tentang strategi. Strategi merupakan cara sebuah organisasi mencapai target/tujuan, dengan melihat peluang dan ancaman lingkungan internal, serta kapasitas dan kemampuan internal organisasi (Jatmiko, 2003). Pernyataan dari Jatmiko tersebut menunjukkan bahwa strategi merupakan komponen penting dalam organisasi untuk mencapai tujuannya, seperti diungkapkan oleh Aldi (20I5) bahwa penting bagi organisasi untuk memiliki kemampuan merencanakan dan mengimplementasikan strategi. Kemudian Jatmiko (2003) mendeskripsikan terdapat tiga faktor yang memberikan pengaruh terhadap strategi, yaitu:

I. Lingkungan eksternal

2. Sumber daya

3. Kemampuan internal dan tujuan yang akan dicapai Strategi juga merupakan seni, hal ini diungkapkan oleh Salusu (2004), bahwa strategi adalah seni dalam mengerahkan kecakapan dan sumber daya suatu organisasi untuk mencapai tujuan dalam kondisi yang paling menguntungkan. Oleh karena itu, strategi memiliki manfaat bagi organisasi, seperti yang disampaikan oleh Dirgantoro (200I), bahwa strategi memiliki manfaat antara lain: 
I. Sebagai sarana penyampaian tujuan organisasi dan penentuan arah yang mana harus ditempuh untuk mencapai tujuan.

2. Meningkatkan koordinasi dan kontrol terhadap proses kegiatan.

3. Sumber daya dapat dikelola menjadi lebih efektif.

4. Mengintegrasikan perilaku

\section{METODOLOGI}

Penelitian ini menggunakan pendekatan deskriptif kualitatif. Seperti diungkapkan oleh Bachri (2010) bahwa pendekatan deskriptif kualitatif ditujukan untuk mendeskripsikan dan menganalisis fenomena, pertistiwa aktifitas sosial, sikap, kepercayaan, persepsi, pemikiran orang secara individual mapupun kelompok. Oleh karena itu, penelitian ini dilakukan untuk memberikan gambaran tentang strategi yang sudah dilakukan oleh BPSDM Provinsi Kalimantan Barat, kemudian memberikan model strategi terbaik sebagai pemecahan masalah. Metode pengumpulan data menggunakan studi literatur, pengumpulan data sekunder, serta dokumentasi.

\section{HASIL DAN PEMBAHASAN}

\section{Strategi Pengembangan Kompetensi yang Telah Dilaksanakan}

I. Melaksanakan Kegiatan Pengembangan Kompetensi Selain Pelatihan

Sejak diberlakukannya PP No. II Tahun 2017, BPSDM Provinsi Kalimantan Barat telah melaksanakan kegiatan pengembangan kompetensi. Berikut adalah kegiatan pengembangan kompetensi yang telah dilaksanakan oleh BPSDM Provinsi Kalimantan Barat tahun 2018-2019:

Tabel III.

Jenis Pengembangan Kompetensi dan Jumlah Alumni BPSDM Prov. Kalbar Tahun 2018-2019

\begin{tabular}{|c|c|c|c|c|}
\hline \multirow[t]{2}{*}{ No } & \multirow[t]{2}{*}{$\begin{array}{l}\text { Jenis Pengembangan } \\
\text { Kompetensi }\end{array}$} & \multicolumn{2}{|c|}{$\begin{array}{l}\text { Jumlah } \\
\text { Alumni } \\
\text { (Tahun) }\end{array}$} & \multirow[t]{2}{*}{ Total } \\
\hline & & 2018 & 2019 & \\
\hline $\mathrm{I}$ & Diklat Kepemimpinan Tk. III-IV & 160 & 40 & 200 \\
\hline 2 & Diklat Pimpemdagri & - & 40 & 40 \\
\hline 3 & $\begin{array}{l}\text { Diklat Prajabatan/Pelatihan } \\
\text { Dasar CPNS }\end{array}$ & 358 & 811 & 1169 \\
\hline 4 & Pelatihan Teknis & 499 & 434 & 933 \\
\hline 5 & Pelatihan Fungsional & 75 & 101 & 176 \\
\hline 6 & Workshop & - & 265 & 265 \\
\hline 7 & Bimbingan Teknis & - & 219 & 219 \\
\hline 8 & $\begin{array}{l}\text { Diseminasi bagi Kepala } \\
\text { Daerah/Jabatan Pimpinan Tinggi }\end{array}$ & 51 & 79 & 130 \\
\hline 9 & Orientasi Anggota DPRD & - & 505 & 505 \\
\hline & Total & $\mathrm{I} .143$ & 2.494 & 3.637 \\
\hline
\end{tabular}

Sumber: BPSDM Prov. Kalbar 2018-2019

Pelatihan secara tatap muka di dalam kelas masih menjadi primadona kegiatan pengembangan kompetensi. Namun mulai tahun 2019, jenis pengembangan kompetensi mengalami diversifikasi, selain pelatihan BPSDM Provinsi Kalimantan Barat juga melaksanakan kegiatan berupa workshop dan bimbingan teknis. Dari 33 jenis pengembangan kompetensi pada tahun 2019, diantaranya terdapat 6 kegiatan workshop dan 5 kegiatan bimbingan teknis.

Dibandingkan dengan pelatihan, workshop dan bimbingan teknis mampu menghasilkan lebih banyak alumni dalam satu kali penyelenggaraan. Misalnya dalam kegiatan Workhsop Tenaga Penguji bagi Tenaga Pengembangan Kompetensi mampu menghasilkan 79 alumni dan Bimbingan Teknis Penulisan KTI bagi Pejabat Fungsional mampu menghasilkan 100 alumni dalam satu kali penyelenggaraan. Dari sisi jumlah hari pelaksanaan workshop dan bimbingan teknis lebih singkat dari pelatihan. Pelatihan dilaksanakan minimal 5 hari, sementara workshop dan bimbingan teknis dapat 
dilaksanakan I-3 hari saja, sehingga dapat menghemat anggaran.

\section{Pada tahun 2019 BPSDM Provinsi} Kalimantan Barat telah memulai melaksanakan pelatihan berbasis blended learning. Model blended learning ini merupakan transformasi model pelatihan yang menyuguhkan ide baru dalam penyampaian, serta peluang baru dalam layanan pelatihan (Fitriyadi, 2013). Pelatihan berbasis blended learning merupakan perpaduan antara pembelajaran mandiri secara e-learning dan pembelajaran klasikal, seperti juga telah diungkapkan oleh Lalima dan Dangwai (2017). Peserta pelatihan melaksanakan pembelajaran mandiri secara e-learning sejumlah hari yang telah ditentukan lewat website yang telah disediakan, di sana peserta dapat mengunduh bahan pembelajaran, melihat video, melakukan pre-test dan post-test, live chat serta mengunggah tugas-tugas yang telah diberikan. Setelah selesai pembelajaran secara e-learning kemudian peserta melaksanakan pembelajaran tatap muka di BPSDM Provinsi Kalimantan Barat. Perbandingan jumlah hari model blended learning ini biasanya 70:30, misalnya jumlah hari pelatihan adalah 10 hari, maka pembelajaran secara e-learning dilaksanakan selama 7 hari dan pembelajaran klasikal dilaksanakan selama 3 hari. Pelatihan teknis biasanya dilaksanakan secara klasikal selama 5-6 hari. Pelatihan dengan model blended-learning ini dapat menghemat anggaran, karena pelaksanaan tatap muka yang hanya $30 \%$ dari jumlah total hari pelatihan.

Dari data di atas, dapat dilihat bahwa terjadi peningkatkan jumlah alumni di tahun 2019 sebesar |35| alumni. Seperti diketahui di awal bahwa jumlah PNS Pemerintah Provinsi Kalimantan
Barat adalah 10.825 PNS, namun kenyataannya BPSDM Provinsi Kalimantan Barat juga melakukan pengembangan kompetensi terhadap PNS dari Pemerintah Kabupaten/Kota di Kalimantan Barat. Jadi total jumlah alumni di atas tidak semua berasal dari PNS di Pemprov Kalimantan Barat. Alumni dari Pemerintah Kabupaten/Kota paling banyak mengikuti Diklat Kepemimpinan Tingkat III/Tingkat IV, Diklat Prajabatan/Pelatihan Dasar CPNS dan Diseminasi. Untuk jenis pengembangan kompetensi Manajerial/Kepemimpinan/Prajabatan terdapat peningkatan sebesar 906 alumni pada tahun 2019. Peningkatan ini disebabkan antara lain oleh adanya penerimaan CPNS sehingga harus mengadakan Pelatihan Dasar CPNS, serta adanya pelantikan anggota DPRD periode 2019-2024 sehingga harus mengadakan kegiatan Orientasi bagi Anggota DPRD Kabupaten/Kota.

Adapun alumni pengembangan kompetensi teknis dan fungsional sebagian besar berasal dari Pemerintah Provinsi Kalimantan Barat. Untuk jenis pengembangan kompetensi teknis dan fungsional terdapat peningkatan sebesar 445 alumni pada tahun 2019. Peningkatan tersebut disebabkan antara lain oleh adanya kegiatan workshop dan bimbingan teknis yang dalam satu kali penyelenggaraan dapat menghasilkan lebih dari 40 alumni.

Tabel IV.

Perbandingan Jumlah Anggaran Pengembangan Kompetensi

\begin{tabular}{|c|c|c|c|}
\hline No & $\begin{array}{c}\text { Jenis } \\
\text { Pengembangan } \\
\text { Kompetensi }\end{array}$ & $\begin{array}{c}\text { Biaya Yang } \\
\text { Dibutuhkan/Kegiatan }\end{array}$ & $\begin{array}{c}\text { Jumlah } \\
\text { Alumni } \\
\text { yang } \\
\text { Dapat } \\
\text { Dihasilkan }\end{array}$ \\
\hline I. & $\begin{array}{c}\text { Diklat } \\
\text { Kepemimpinan } \\
\text { Tingkat III }\end{array}$ & Rp 885.000.000,- & 40 \\
\hline 2. & $\begin{array}{c}\text { Diklat } \\
\text { Kepemimpinan } \\
\text { Tingkat IV }\end{array}$ & Rp. 809.200.000,- & 40 \\
\hline 3. & $\begin{array}{c}\text { Pelatihan Dasar } \\
\text { CPNS }\end{array}$ & Rp 37I.840.000,- & 40 \\
\hline
\end{tabular}




\begin{tabular}{|c|c|c|c|}
\hline 4. & $\begin{array}{l}\text { Pelatihan Teknis } \\
\text { dan Fungsional } \\
\text { secara klasikal }\end{array}$ & $\begin{array}{l}\text { Rp I 60.747.400,- } \\
\text { sampai dengan } \\
\text { Rp I 87.847.400,- }\end{array}$ & 40 \\
\hline 5. & $\begin{array}{l}\text { Pelatihan yang } \\
\text { berbasis blended } \\
\text { learning }\end{array}$ & Rp 79.345.200,-, & 40 \\
\hline 6. & Workshop & $\begin{array}{c}\text { Rp 86.819.800,- sampai } \\
\text { dengan } \\
\text { Rp I52.648.700,- }\end{array}$ & $\begin{array}{c}\text { Lebih dari } \\
40\end{array}$ \\
\hline 7. & Bimbingan Teknis & $\begin{array}{c}\text { Rp I I5.295.200,- sampai } \\
\text { dengan } \\
\text { Rp 207.290.200,- }\end{array}$ & $\begin{array}{c}\text { Lebih dari } \\
40\end{array}$ \\
\hline
\end{tabular}

Sumber: BPSDM Prov. Kalbar 2018-2019

\section{Diklat Kepemimpinan dan Pelatihan Dasar}

CPNS memerlukan pembiayaan yang cukup besar setiap penyelenggaraannya, dan BPSDM harus menyelenggarakannya karena merupakan kegiatan prioritas yang harus dilaksanakan. Jika melakukan perbandingan dengan pengembangan kompetensi selain Diklat Kepemimpnan dan Pelatihan Dasar CPNS, maka pelatihan berbasis blended learning menempati urutan pembiayaan termurah dibandingkan dengan pelatihan teknis/fungsional klasikal, workshop dan bimbingan teknis. Namun workshop dan bimbingan teknis dapat menghasilkan jumlah alumni yang lebih banyak dibandingkan dengan pelatihan. Meskipun demikian pelaksanaan pelatihan berbasis blended learning, workshop dan bimbingan teknis lebih hemat dibandingkan dengan pelatihan klasikal.

Berdasarkan pemaparan di atas, BPSDM dapat melakukan dua hal dalam mengembangankan kegiatan pengembangan kompetensi selain pelatihan, yaitu:

a. Memperbanyak kegiatan pelatihan berbasis blended learning, workshop dan bimbingan teknis.

$\mathrm{Hal}$ tersebut dapat menghemat pembiayaan dalam satu kali penyelenggaraan, sehingga dengan penghematan tersebut dapat dialokasikan untuk menyelenggarakan kegiatan pengembangan kompetensi lainnya. Selain itu, pada saat tahap pembelajaran e-learning, peserta dapat belajar kapan saja dan dimana saja (Nadziroh, 2017). Selain itu pelaksanaan workshop dan bimbingan teknis dapat menghasilkan jumlah alumni lebih banyak dalam satu kali penyelenggaraan dibandingkan dengan pelatihan.

b. Melakukan pengembangan kurikulum. Untuk memperbanyak pelatihan berbasis blended learning atau full e-learning, BPSDM dapat mengembangkan kurikulum yang mendukung pelaksanaan strategi pengembangan kompetensi. Seperti diungkapkan oleh Fajri (2019) bahwa pengembangan kurikulum dapat disesuaikan dengan strategi untuk mencapai tujuan yang diinginkan. Nurhajati dan Bahcri (2017) juga mengungkapkan pentingnya pengembangan kurikulum untuk menjawab tantangan pengemabangan kompetensi di masa mendatang. Adapun BPSDM telah mengembangkan pelatihan Tata Naskah Dinas yang semula klasikal menjadi blended learning. Diharapkan BPSDM dapat mengembangkan kurikulum untuk pelatihannya lainnya menjadi model blended learning atau full e-learning.

Meskipun BPSDM Provinsi Kalimantan Barat telah menyelenggarakan kegiatan pengembangan kompetensi baik secara klasikal maupun blended learning, namun belum mampu memenuhi kebutuhan pengembangan kompetensi bagi 10.825 PNS di Pemrpov Kalimantan Barat. Pengembangan kompetensi secara klasikal dan blended learning terbatas pada ketersediaan anggaran, ketersediaan fasilitas dan tenaga pengajar di BPSDM Provinsi Kalimantan Barat. 
2. Rapat Koordinasi Pengembangan Kompetensi

Dalam menentukan program pengembangan kompetensi yang akan dilaksanakan, sejak PP No. II Tahun 2017 diundangkan, setiap tahunnya BPSDM Provinsi Kalimantan Barat menyelenggarakan Rapat Koordinasi Pengembangan Kompetensi dengan seluruh unit kerja di lingkungan Pemprov Kalimantan Barat. Dalam rapat koordinasi yang dilaksanakan dengan metode focus group discussion (FGD), BPSDM Provinsi Kalimantan Barat menghimpun usulan kegiatan pengembangan kompetensi dari seluruh unit kerja. Unit kerja menyampaikan usulan berdasarkan data kesenjangan kompetensi PNS yang ada di unit kerjanya. Hal tersebut juga didukung oleh Hermawan dan Ngindana (2019) bahwa unit kerja dapat melakukan analisis kesenjangan kinerja dan kesenjangan kompetensi untuk menentukan kebutuhan pengembangan kompentensi bagi pegawainya.

Selain melakukan rapat koordinasi, di awal tahun BPSDM Provinsi Kalimantan Barat menyampaikan surat kepada seluruh unit kerja untuk menyampaikan usulan kegiatan pengembangan kompetensi. Kegiatan rapat koordinasi dan penyampaian surat tentang usulan kegiatan pengembangan kompetensi merupakan strategi BPSDM Provinsi Kalimantan Barat untuk menentukan jenis kegiatan pengembangan kompetensi yang akan dilaksanakan. Sebelumnya BPSDM Provinsi Kalimantan Barat menyelenggarakan kegiatan Analisis Kebutuhan Pengembangan Kompetensi (AKPK), namun setelah PP No. II Tahun 2017 terbit, maka kegiatan AKPK diambil alih oleh Badan Kepegawaian Daerah (BKD) Provinsi Kalimantan Barat.

\section{Dengan demikian BPSDM Provinsi} Kalimantan Barat menentukan jenis kegiatan pengembangan kompetensi yang akan dilaksanakan berdasarkan masukan dari rapat koordinasi, surat tanggapan dari setiap unit kerja terhadap usulan kegiatan pengembangan kompetensi, dan hasil AKPK dari BKD Provinsi Kalimantan Barat. Tentu BPSDM Provinsi Kalimantan Barat tidak dapat memenuhi semua kebutuhan pengembangan kompetensi yang diharapkan karena keterbatasan anggaran, fasilitas dan tenaga pengajar. Oleh karena itu, BPSDM Provinsi Kalimantan Barat menentukan prioritas kegiatan pengembangan kompetensi yang akan dilaksanakan dan menyesuaikannya dengan visi-misi pemerintah pusat dan pemerintah daerah.

3. Peraturan Gubernur Kalimantan Barat Nomor 128 Tahun 2019 tentang Pengembangan Kompetensi PNS di Provinsi Kalimantan Barat

Dalam rangka mendukung kegiatan pengembangan kompetensi yang sudah diamanatkan oleh UU No. 5 Tahun 2014 dan PP I I Tahun 2017, maka di awal tahun 2019 BPSDM Provinsi Kalimantan Barat menginisiasi pembuatan Peraturan Gubernur tentang Pengembangan Kompetensi PNS di Provinsi Kalimantan Barat. Peraturan Gubernur ini dijadikan pedoman penyelenggaraan pengembangan kompetensi di lingkungan pemprov. Tujuan dari Peraturan Gubernur tersebut adalah untuk memberikan landasan hukum dalam penyelenggaraan pengembangan kompetensi; meningkatkan efektifitas dan efisiensi dalam penyelenggaraan pengembangan kompetensi; dan mewujudkan penyelenggaraan pengembangan kompetensi yang tertib, transparan dan akuntabel. 
Dalam Peraturan Gubernur tersebut, bentuk pengembangan kompetensi dapat dilakukan melalui pendidikan dan pelatihan. Pengembangan kompetensi melalui pendidikan dilakukan melalui pemberian tugas belajar dan izin belajar dalam jenjang pendidikan tinggi. Untuk pelaksanaan pengembangan kompetensi melalui pelatihan, dapat dilakukan melalui pelatihan klasikal dan pelathan nonklasikal.

Pelatihan kalsikal dilakukan melalui kegiatan yang menekankan pada proses pembelajaran tatap muka di dalam kelas. Pelatihan klasikal dapat dilakukan antara lain melalui pelatihan manajerial, pelatihan teknis, pelatihan fungsional, pelatihan sosial kultural, seminar/konferensi/ sarasehan, workshop/lokakarya, kursus, penataran, bimbingan teknis dan sosialisasi.

Pelatihan nonklasikal dilakukan melalui kegiatan yang menekankan pada proses pembelajaran praktik kerja dan/atau pembelajaran di luar kelas. Pelatihan nonklasikal dapat dilakukan antara lain melalui coaching, mentoring, e-learning, pelatihan jarak jauh, detasering (secondment), pembelajaran alam terbuka (outbond), patok banding (benchmarking), pertukaran PNS dengan pegawai swasta/BUMN/BUMD, belajar mandiri, bimbingan di tempat kerja dan magang.

Pemenuhan akan 20 JP bagi setiap PNS per tahun juga menjadi fokus dalam Peraturan Gubernur tersebut. Dengan semakin banyaknya jenis pengembangan kompetensi, maka setiap unit kerja dapat menyelenggarakan sendiri atau bekerja sama dengan BPSDM Provinsi Kalimantan Barat, juga dapat bekerja sama dengan instansi pemerintah/lembaga pelatihan lainnya unutk melaksanakan kegiatan pengembangan kompetensi.
Untuk penyelenggaraan pelatihan klasikal yang diselenggarakan oleh unit kerja maka harus mendapatkan rekomendasi/izin penyelenggaraan dari BPSDM Provinsi Kalimantan Barat.

Untuk mewujudkan pengembangan kompetensi terintegrasi yang tertib, transparan dan akuntabel, maka setiap unit kerja menunjuk Agen Pengembangan Kompetensi (Abang Kompetensi). Nantinya setiap Abang Kompetensi akan melaporkan data PNS yang telah mengikuti kegiatan pengembangan kompetensi di unit kerjanya. Diharapkan setelah semua data terkumpul dari semua unit kerja, maka dapat dilihat berapa jumlah PNS yang mengikuti pengembangan kompetensi, apa saja jenisnya, berapa banyak jumlah JP dan sejauh mana pengembangan kompetensi yang diikuti relevan dengan kompetensi bidang tugas jabatannya.

\section{Mencari Model Strategi Terbaik}

Sebagai awal dalam mencari model strategi, dilakukan simulasi terhadap kebutuhan anggaran dan jumlah alumni yang dapat dihasilkan berdasarkan beberapa jenis pengembangan kompetensi yang memungkinkan.

Tabel V.

Simulasi Model Pemenuhan 20 JP Berdasarkan Anggaran yang Dibutuhkan

\begin{tabular}{|l|c|c|c|}
\hline $\begin{array}{c}\text { Jenis } \\
\text { Pengembangan } \\
\text { Kompetensi }\end{array}$ & $\begin{array}{c}\text { Biaya/orang } \\
\text { (Rupiah) *) }\end{array}$ & $\begin{array}{c}\text { Kapasitas } \\
\text { orang **) }\end{array}$ & $\begin{array}{c}\text { Biaya Total } \\
\text { (Rupiah) }\end{array}$ \\
\hline Pelatihan klasikal*) & 4.600 .000 & 40 & 138.000 .000 \\
\hline $\begin{array}{l}\text { Pletaihan blended } \\
\text { learning }\end{array}$ & 2.500 .000 & 40 & 100.000 .000 \\
\hline $\begin{array}{l}\text { Pelatihan full e- } \\
\text { learning }\end{array}$ & - & 10.825 & - \\
\hline Workshop/Seminar & 2.000 .000 & 100 & 200.000 .000 \\
\hline Bimbingan teknis & 2.000 .000 & 100 & 200.000 .000 \\
\hline Pemagangan & 10.000 .000 & 20 & 200.000 .000 \\
\hline Coaching & - & 10.825 & - \\
\hline $\begin{array}{l}\text { On the job training } \\
\text { (OJT) }\end{array}$ & 170.277 & 10.825 & 1.843 .250 .000 \\
\hline
\end{tabular}


*) Pelatihan yang dihitung merupakan jenis pelatihan teknis dan fungsional dengan pelaksanaan selama 5-6 hari.

**) Asumsi berdasarkan beberapa ketentuan dan data di BPSDM Prov. Kalbar dengan membagi jumlah anggaran dengan target peserta.

***) Asumsi berdasarkan beberapa ketentuan dan rata-rata jumlah alumni per jenis kegiatan pengembangan kompetensi di BPSDM Prov. Kalbar.

Dari asumsi simulasi di atas dapat diketahui bahwa pelatihan full e-learning dan coaching tidak membutuhkan biaya dengan target peserta maksimal. Pelatihan full e-learning mempunyai kelebihan pada kemudahan pemakaiannya yang dapat diakses dimana pun dan kapan pun. Meskipun BPSDM telah mempunyai fasilitas penunjang e-learning, namun akan sulit bagi BPSDM untuk memantau semua kelas pelatihan dengan full e-learning dengan pesertanya adalah seluruh PNS. Pelaksanaan coaching bisa dilakukan oleh atasan langsung PNS, namun coaching di tempat kerja terbatas hanya pada teknis pelaksanaan tugas sehari-hari.

Model pengembangan kompetensi yang juga hemat dengan cakupan peserta terbanyak adalah on the job training (OJT). Model ini sangat memungkinkan dilakukan oleh BPSDM. OJT dilakukan di tempat kerja, dimana pegawai mempelajari pekerjaan mereka, di bawah pengawasan langsung (Dewi, 2018). Dalam pengembangan kompetensi PNS, OJT mempunyai manfaat praktis yaitu pegawai langsung belajar bagaimana mengerjakan semua tugasnya (Sudarto, 2012). Meskipun OJT juga bisa dilakukan oleh unit kerja yang bersangkutan, namun sebagai leading sector pengembangan kompetensi BPSDM dapat melakukannya dengan didukung ketersediaan waktu dan tenaga pengajar.

$\begin{array}{cccc} & \text { Model OJT dapat dilakukan oleh } & \text { BPSDM } \\ \text { dengan } & \text { mengerahkan seluruh } & \text { tenaga }\end{array}$ pengajarnya/Widyaiswara untuk turun ke semua unit kerja. BPSDM memiliki jumlah Widyaiswara sebanyak 2 I orang yang memiliki kompetensi dan spesialisasi mata pelatihan yang berbeda-beda. Berdasarkan data yang diolah dari data kompetensi dan spesialisasi, maka Widyaiswara BPSDM Provinsi Kalimantan Barat memiliki kompetensi dan spesialisasi untuk memberikan materi antara lain yang berkaitan dengan:

I. Akuntabilitas

2. Nasionalisme

3. Etika Publik

4. Komitmen Mutu

5. Anti Korupsi

6. Pelayanan Publik

7. Whole of Governance

8. Inovasi

9. Kepemimpinan

10. Keuangan Daerah

II.Pemerintahan

12. Kebijakan Publik

13. Pengadaan Barang/Jasa Pemerintah

14. Pengembangan Diri Aparatur

15. Perencanaan

16. Gender

17. Revolusi Mental

18. Manjemen Bencana

19. Teknik/Pekerjaan Umum

20. Lingkungan Hidup

21. Keguruan

22. Kearsipan

23. Tata Naskah Dinas

Dengan kompetensi dan spesialisasi yang dimiliki oleh Widyaiswara, maka tema pelaksanaan pengembangan kompetensi melalui OJT dapat bervariasi mengikuti unit kerja yang akan didatangi. Karena setiap unit kerja memiliki teknis substansi yang bisa berbeda dengan kompetensi yang dimiliki oleh Widyaiswara, maka bisa juga OJT akan mengambil tema yang umum dan relevan dengan tupoksi unit 
kerja serta relevan dengan isu terkini, seperti tema anti korupsi, hidup dalam keberagaman dan revolusi industri 4.0.

Terdapat 47 unit kerja di Pemprov Kalbar (termasuk Biro di Sekretariat Daerah), dengan total seluruh pegawai sebanyak 10.825 PNS. Oleh karena Pemprov Kalbar memiliki Unit Pelaksana Teknis (UPT) yang tersebar di I4 kabupaten/kota se-Kalimantan Barat, BPSDM juga bisa melakukan OJT dengan mengunjungi UPT di kabupaten/kota. BPSDM dapat berkoordinasi dengan unit kerja dapat bagaimana solusi mekanisme pembiayaannya. Hal ini sudah biasa dilakukan oleh BPSDM mengingat Pemerintah Kabupaten/Kota di Kalimantan Barat sering meminta tenaga pengajar ke BPSDM untuk kegiatan pengembangan kompetensi.

Rata-rata jumlah pegawai setiap unit kerja adalah 100-200 PNS, kecuali tiga rumah sakit milik Pemprov Kalbar yang memiliki I.44I PNS, yang sebagian besar merupakan tenaga kesehatan, serta Dinas Pendidikan dan Kebudayaan memiliki 5.395 PNS yang sebagian besar tenaga guru. Diasumsikan untuk satu kali pelaksanaan OJT jumlah pesertanya adalah 100 PNS, untuk rumah sakit dan Dinas Pendidikan dan Kebudayaan dapat dilakukan beberapa kali OJT, mengikuti besar jumlah pegawainya. Dengan demikian untuk melaksanakan OJT bagi I0.825 PNS diperlukan 109 kali penyelenggaraan OJT.

Dengan jumlah 21 Widyaiswara, dan diasumsikan untuk pelaksanaan OJT sebanyak $20 \mathrm{JP}$ paling singkat membutuhkan waktu 2 hari, maka untuk melaksanakan model ini sebanyak 109 kali,dapat dilakukan simulasi sebagai berikut:

Tabel VI.

Simulasi Jumlah Hari Pelaksanaan OJT

\begin{tabular}{|c|c|c|c|}
\hline $\begin{array}{c}\text { Hari } \\
\text { Pelaksanaan }\end{array}$ & $\begin{array}{c}\text { Widyaiswara } \\
\text { yang Dibutuhkan }\end{array}$ & $\begin{array}{c}\text { Jumlah } \\
\text { OJT }\end{array}$ & $\begin{array}{c}\text { Jumlah } \\
\text { Peserta }\end{array}$ \\
\hline Hari ke I-2 & 2 I & 2I & 2.100 \\
\hline Hari ke 3-4 & 2I & 2I & 2.100 \\
\hline
\end{tabular}

\begin{tabular}{|c|c|c|c|}
\hline $\begin{array}{c}\text { Hari } \\
\text { Pelaksanaan }\end{array}$ & $\begin{array}{c}\text { Widyaiswara } \\
\text { yang Dibutuhkan }\end{array}$ & $\begin{array}{c}\text { Jumlah } \\
\text { OJT }\end{array}$ & $\begin{array}{c}\text { Jumlah } \\
\text { Peserta }\end{array}$ \\
\hline Hari ke 5-6 & $2 I$ & $2 I$ & 2.100 \\
\hline Hari ke 7-8 & $2 I$ & $2 I$ & 2.100 \\
\hline Hari ke 9-10 & $2 I$ & $2 I$ & 2.100 \\
\hline Hari ke II-12 & 4 & 4 & 325 \\
\hline Total & 109 & 109 & 10.825 \\
\hline
\end{tabular}

Dari simulasi tersebut didapat gambaran bahwa dengan model OJT BPSDM dapat mengembangkan kompetensi bagi 10.825 PNS di Pemprov Kalbar dalam waktu hanya 12 hari.

Kemudian bagaimana jika penyelenggaraan model OJT divisualisasikan dalam rencana biaya? Dalam simulasi rencana biaya ini tidak mengambil semua aspek pembiayaan, hanya mengambil dari honorarium Widyaiswara dan konsumsi peserta, dengan asumsi honorarium Widyaiswara per JP sebesar Rp 200.000,-, satu kali makan Rp 35.000,- dan satu kali snack Rp 15.000,-.

Tabel VII.

Asumsi Pembiayaan OJT

\begin{tabular}{|c|c|c|c|}
\hline Aspek Pembiayaan & $\begin{array}{c}\text { Volu- } \\
\text { me }\end{array}$ & $\begin{array}{c}\text { Harga } \\
\text { Satuan } \\
\text { (Rupiah) }\end{array}$ & $\begin{array}{c}\text { Jumlah } \\
\text { (Rupiah) }\end{array}$ \\
\hline $\begin{array}{c}\text { Honorarium } \\
\text { Widyaiswara } \\
\text { I09 penyelenggaraan } \\
\text { x 20 JP) }\end{array}$ & 2.180 & 200.000 & 436.000 .000 \\
\hline $\begin{array}{c}\text { Makan Siang } \\
\text { (I kali x I0.825 org x } \\
\text { 2 hari) }\end{array}$ & 21.650 & 35.000 & 757.750 .000 \\
\hline $\begin{array}{c}\text { Snack Harian } \\
\text { (2 kali x I0.825 org x } \\
\text { 2 hari) }\end{array}$ & 43.300 & 15.000 & 649.500 .000 \\
\hline \multicolumn{3}{|c|}{ Total } & 1.843 .250 .000 \\
\hline
\end{tabular}

Jika simulasi pembiayaan OJT dibandingkan dengan biaya yang dianggarkan oleh BPSDM untuk penyelenggaraan berbagai kegiatan pengembangan kompetensi (pelatihan, workshop, bimbingan teknis, diseminasi) pada tahun 2018-2019, maka dapat dilihat pada tabel berikut:

Tabel VIII.

Perbandingan Pembiayaan OJT dengan Pengembangan Kompetensi yang Telah Dilaksanakan

\begin{tabular}{|c|c|c|}
\hline $\begin{array}{c}\text { Kegiatan Pengembangan } \\
\text { Kompetensi }\end{array}$ & $\begin{array}{c}\text { Biaya yang } \\
\text { Dibutuhkan } \\
\text { (Rupiah) }\end{array}$ & $\begin{array}{c}\text { Jumlah } \\
\text { Alumni yang } \\
\text { Dihasilkan }\end{array}$ \\
\hline Kegiatan Pengembangan & 8.136 .794 .200 & I.143 \\
\hline
\end{tabular}




\begin{tabular}{|c|c|c|}
\hline $\begin{array}{c}\text { Kegiatan Pengembangan } \\
\text { Kompetensi }\end{array}$ & $\begin{array}{c}\text { Biaya yang } \\
\text { Dibutuhkan } \\
\text { (Rupiah) }\end{array}$ & $\begin{array}{c}\text { Jumlah } \\
\text { Alumni yang } \\
\text { Dihasilkan }\end{array}$ \\
\hline Kompetensi Tahun 2018 & & \\
\hline $\begin{array}{c}\text { Kegiatan Pengembangan } \\
\text { Kompetensi Tahun 2019 }\end{array}$ & 18.456 .454 .537 & 2.494 \\
\hline On The Job Training (OJT) & 1.843 .250 .000 & 10.825 \\
\hline
\end{tabular}

Sumber: BPSDM Prov. Kalbar Tahun 2018-2019 dan hasil simulasi pembiayaan OJT

Dari simulasi pembiayaan, dapat dilihat bahwa model OJT ini lebih hemat dan mampu menghasilkan alumni lebih banyak dibandingkan dengan model pengembangan kompetensi lainnya. BPSDM dapat melakukan koordinasi dengan unit kerja terkait skema pembiayaannya.

Kelebihan yang lain dari program ini antara lain adalah waktu pelaksanaan bisa fleksibel. Dari simulasi di dapat angka 12 hari untuk menyelenggarakan 109 OJT, bukan berarti dilaksanakan selama 12 hari kerja berturut-turut, namun dapat dilaksanakan sepanjang tahun menyesuaikan dengan kepadatan jadwal Widyaiswara dan kondisi/situasi di unit kerja. Bahkan pelaksanaan OJT dengan waktu 20 JP bisa fleksibel dilaksanakan lebih dari 2 hari, tergantung dari situasi dan kondisi unit kerja, serta kompetensi yang ingin dicapai. Selain itu, peserta tidak perlu datang ke tempat pelatihan karena Widyaiswara sendiri datang 'jemput bola' ke unit kerja, sehingga lebih efisien dan efektif.

Kelemahan yang dapat muncul dari pelaksanaan program ini adalah kepadatan jadwal mengajar Widyaiswara di BPSDM Provinsi Kalimantan Barat, sehingga sulit untuk mengajar di luar BPSDM. Selain itu bisa jadi jadwal yang sudah ditentukan mendadak batal karena kesibukan di unit kerja yang akan didatangi. Selanjutnya, tidak semua OJT nantinya dapat membahas hal-hal yang teknis terkait bidang tugas jabatan, karena peserta dari setiap unit kerja memiliki kompetensi teknis jabatan yang berbeda-beda, sehingga diasumsikan materi yang akan diberikan adalah materi yang bersifat umum..

Dengan model OJT Pemerintah Provinsi Kalimantan Barat dimungkinkan untuk menjadi pemerintah provinsi yang dapat memenuhi jam wajib pengembangan kompetensi bagi seluruh pegawainya. Untuk pelaksanaan program ini, diperlukan koordinasi dan kolaborasi yang baik antara BPSDM Provinsi Kalimantan Barat dengan seluruh unit kerja. Selain itu komitmen pimpinan setiap unit kerja juga diperlukan untuk pelaksanaan program ini. Program ini dapat dimasukkan juga dalam surat edaran atau Peraturan Gubernur supaya mempunyai landasan yang kuat.

\section{KESIMPULAN}

Dengan terbitnya PP No. II Tahun 2017, BPSDM Provinsi Kalimantan Barat telah melaksanakan strategi pengembangan kompetensi dalam rangka pemenuhan pengembangan kompetensi sebanyak $20 \mathrm{JP}$ bagi setiap PNS per tahun. BPSDM Provinsi Kalimantan Barat telah melaksanakan program pelatihan dan telah mengembangkan program pelatihan seperti workshop, bimbingan teknis dan pelatihan berbasis blended learning. Namun karena keterbatasan fasilitas dan anggaran, BPSDM belum dapat menampung semua PNS di Pemprov Kalbar untuk mengikuti pengembangan kompetensi di BPSDM.

Dari hasil penelitian ini, maka dapat disarankan hal-hal sebagai berikut:

I. BPSDM dapat membuat program pengembangan kompetensi selain pelatihan klasikal, seperti pelatihan berbasis blended learning, workshop dan bimbingan teknis dengan biaya yang lebih murah dan dapat menghasilkan jumlah alumni yang banyak. Untuk mendukung hal tersebut maka disarankan agar BPSDM melakukan pengembangan kurikulum yang menyesuaikan dengan perkembangan 
teknologi informasi dan menyesuaikan dengan tujuan/visi-misi yang diinginkan.

2. BPSDM dapat menggunakan model on the job training (OJT). Melalui model ini, Widyaiswara akan mengajar dengan mendatangi setiap unit kerja. Berdasarkan simulasi, maka untuk mengembangkan kompetensi bagi 10.825 PNS diperlukan dalam waktu 12 hari untuk pelaksanaan 109 OJT, dengan jumlah pembiayaan sebesar Rp I.843.250.000,-. Program ini memiliki kelebihan dan kekurangannya, namun dengan simulasi yang telah dilakukan, Pemerintah Provinsi Kalimantan Barat dimungkinkan untuk menjadi pemerintah provinsi yang dapat memenuhi jam wajib pengembangan kompetensi bagi seluruh pegawainya.

3. Oleh karena penelitian ini dilakukan dengan menggunakan metode yang sederhana, diharapkan agar peneliti selanjutnya melakukan penelitian dengan menggunakan metode yang lebih komprehensif.

\section{REFERENSI}

Aldi, B. Elnath. (20I5). Upaya Generalisasi Konsep Manajemen Strategik. Jurnal IImu Ekonomi dan Sosial. VI (2), 56-72.

Apandi. (2020). Strategi Peningkatan Kompetensi Aparatur Sipil Negara Melalui Peningkatan ELiterasi dan Edukasi Kebijakan Publik. Cendekia. I 4 (I), 33-42.

Ayas, Dafa Romi dan Kariaman Sinaga. (2019). Analisis Strategi Pengembangan Sumber Daya Aparatur dalam Meningkatkan Kinerja Pegawai di Badan Kepegawaian Serdang Bedagai. Jurnal Publik Reform UNDHAR MEDAN. Edisi 5 Januari-Juni 2019, 40-5I.

Bachri, Bachtiar. (2010). Meyakinkan Validitas Data Melalui Triangulasi pada Penelitian Kualitatif. Jurnal Teknologi Pendidikan. 10 (I), 46-62.
Burkholder, Nicholas C., Scot Golas and Jeremy Shapiro. (2007). Ultimate Performance Measuring Human Resources at Work. New Jersey: John Wiley \& Sons, Inc.

Dewi, Santi Riana. (2018). Analisis Dominasi Pengaruh On the Job Training terhadap Peningkatan Kualitas Kinerja. Jurnal Manajemen. 8 (I), I-9.

Dirgantoro, Crown. (200I). Manajemen strategik: Konsep, Kasus, dan Implementasi. Jakarta: PT Grasindo.

Fajri, Krima Nabila. (2019). Proses Pengembangan Kurikulum. Jurnal Keislaman dan Ilmu Pendidikan. I (2), 35-48.

Fathurrochman, Irwan. (2017). Pengembangan Kompetensi Pegawai Aparatur Sipil Negara (ASN) Sekolah Tinggi Agama Islam Negeri (STAIN) Curup melalui Metode Pendidikan dan Pelatihan. Manajer Pendidikan. II (2I), I20-I29.

Fitriyadi, Herry. (20I3). Integrasi Teknologi Informasi Komunikasi dalam Pendidikan: Potensi Manfaat, Masyarakat Berbasis Pengetahuan, Pendidikan Nilai, Strategi Implementasi dan Pengembangan Profesional. Jurnal Pendidikan Teknologi dan Kejuruan. 2 I (3), 269-284.

Ngindana, Rispa dan Romy Hermawan. (2019). Analisis Kebutuhan Diklat Pegawai Negeri Sipil Berbasis Kesenjangan Kerja Unit Kerja di Lingkungan Pemerintah Kota Mojokerto. Jurnal Inovasi IImu Sosial dan Politik. I (I), I-I I.

Ismail, Zulaeha, Anwar dan Mulia Halim. (2018). Strategi Pimpinan dalam Meningkatkan Kinerja Pegawai (Studi Kasus pada Dinas Pendidikan dan Kebudayaan Provinsi Sulawesi Tenggara). Jurnal Wahana Kajian Pendidikan IPS. 2 (I), 203214.

Jatmiko. (2003). Manajemen Strategi. Malang: UMM Press.

Lalima and Kiran Lata Dangwai. (2017). Blended Learning: An Innovative Approach. Universal Kournal of Educational Research. 5 (I), 129-136.

Madjid, Noor Cholis. (2019). Tantangan Menghasilkan Diklat yang Berkualitas dan Berdampak Luas. Jurnal Inspirasi. 10 (I), 49-55. 
Muda, Raja. (2019). Standar Kompetensi Manajerial Pegawai Negeri Sipil di Badan Pengembangan Sumber Daya Manusia Aceh (Studi Deskripsi Keterkaitan Kompetensi Manajerial dan Kinerja Organisasi). Jurnal Transformasi Administrasi. 09 (0I), 2 I-35.

Mulyaningsih. (2020). Analisis Kebutuhan Pelatihan Teknis dalam Meningkatkan Kompetensi Pegawai Negeri Sipil. Jurnal Jendela Inovasi Daerah. III (I), 87-I00.

Nadziroh, Faridatun. (2017). Analisa Efektifitas Sistem Pembelajaran Berbasis E-Learning. Jurnal IImu Komputer dan Desain Komunikasi Visual. 2 (I), I14.

Nurhajati, Widi Asih dan Bachtiar Sjaiful Bachri. (2017). Pengembangan Kurikulum Pendidikan dan Pelatihan (Diklat) Berbasis Kompetensi dalam Membangun Profesionalisme Pegawai Negeri Sipil (PNS). Jurnal Pendidikan (Teori dan Praktik). 2 (2), I56-I64.

Salusu. J. (20I5). Pengambilan Keputusan Stratejik untuk Organisasi Publik dan Organisasi Nonprofit. Jakarta: PT Grasindo.

Sudarto. (20/2). Pengaruh Kompetensi Pembimbingan dan Kompetensi Instruktur terhadap Kefektifan Pelaksanaan On The Job Training. Educational Management. I (I), 26-32.

Sultoni. (2020). Strategi Pengembangan Sumber Daya Manusia melalui Analisis Kebutuhan Diklat di BPSDM Provinsi Jambi. Jurnal Ilmu Manajemen Terapan. I (3), 2 I।-2। 7.

Sumanti, Rati. (20/8). Pengembangan Kompetensi Pegawai Negeri Sipil di Daeah: Tantangan dan Peluang. Jurnal Transformasi Administrasi. 08 (02), II5-129.

Setiadiputra, Raden Yudhy Pradityo. (2017). Urgensi Program Pengembangan Kompetensi SDM Secara Berkesinambungan di Lingkunagn Instansi Pemerintah. Jurnal SAWALA. 5 (I), I622.

Sunusi, Syamsul. (20I5). Strategi Kebijakan Pengembangan Sumber Daya Aparatur Pemerintah Daerah Kabupaten Sidenreng Rappang. Jurnal Administrasi Publik. 5 (2), I44153.

\section{Perundang-Undangan}

Undang-Undang Nomor 4 Tahun 2014 tentang Aparatur Sipil Negara.

Peraturan Pemerintah Nomor II Tahun 2017 tentang Manajemen Pegawai Negeri Sipil.

Peraturan Lembaga Administrasi Negara Republik Indonesia Nomor 10 Tahun 2018 tentang Pengembangan Kompetensi Pegawai Negeri Sipil. 